AP06

Middle Jurassic to Early Cretaceous Petroleum Systems of the Arabian Plate

G.J. Grabowski* (ExxonMobil Exploration Company), D.E. Sherrett (ExxonMobil Exploration Company), T.W. Jones (ExxonMobil Exploration Company), W.B. Maze (ExxonMobil Exploration Company) \& J. Kendall (ExxonMobil Exploration Company)

For abstract, PTO

No full paper available 


\section{Middle Jurassic to Early Cretaceous petroleum systems of the Arabian Plate}

George J. Grabowski, Jr. ((ExxonMobil < george.grabowski@exxonmobil.com>), Danielle E. Sherrett (ExxonMobil) Tom W. Jones (ExxonMobil), Will B. Maze (ExxonMobil) and Jerry Kendall (ExxonMobil)

What are arguably the most prolific petroleum systems in the world are driven by multiple world-class source rocks. These highly organic-rich rocks account for most of the discovered oil and gas on the Arabian Plate. The source rocks were deposited in widespread shallow-marine intra-shelf basins and deep-marine basins. They differ in age between basins and are not correlative with global occurrences of organic enrichment.

Burial under Mesozoic and Cenozoic strata has caused the source rocks to generate oil and gas. Timing of generation differs mainly by variations in sedimentary load; differences in the kinetics of generation and regional heat flow play a lesser role. In the west of the Arabian Plate, generation occurred under Cretaceous and Paleogene sedimentary load, whereas in and near the Zagros Foldbelt generation continues under recent syntectonic sedimentary load.

The most organic-rich source rocks are carbonates containing mainly marine (Type-I/ II) organic matter that has generated sulfur-bearing oil and gas. The gas in some carbonate reservoirs is further enriched in $\mathrm{H}_{2} \mathrm{~S}$ derived from thermal-sulfate reduction. Clay-rich source rocks contain a mixture of marine and land-plant (Type II/III) organic matter and have generated a mixture of low-sulfur oil and gas. Gas is more common also where the source rocks are deeply buried and more thermally mature.

Low-angle structural dip of highly continuous strata allowed oil and gas to migrate laterally for greater than $150 \mathrm{~km}$ from areas of generation to traps, limited only by the extent of structural dip and continuous seal. Intervals of widespread evaporite and shale acted as barriers to vertical migration. Oil and gas migrated to younger rocks through gaps in migration barriers caused by non-deposition or erosion, including localized karst dissolution, or by faults that pierce these migration barriers, commonly where they are thin. Oil and gas generated from Jurassic and Early Cretaceous source rocks are found in many Jurassic, Cretaceous and Cenozoic reservoirs, but rarely occur in older rocks.

The Arabian Plate is reservoir rich, with multiple reservoir-seal pairs for oil and gas accumulations. Most reservoir rocks are shallow-marine carbonates and paralic sandstones, but non-marine and deepmarine sedimentary rocks and even fractured basement are reservoirs in some basins. Shallow burial and limited cementation in the subsurface have favored preservation of porosity and some superb reservoir quality.

Most traps are structural. Compressional thrusted anticlines dominate the Zagros Foldbelt, whereas compressional anticlines with reactivated basement-involved faults occur on the Arabian Platform. Halokinesis of deeply buried Neoproterozoic-Cambrian salt forms traps, especially in the offshore Gulf and in Oman. Extensional faulted anticlines form traps in rift basins, notably in Syria and Yemen. The few discovered stratigraphic traps include truncation pinchouts and reefal buildups. 